\title{
DNA damage and cytotoxicity in pathology laboratory technicians exposed to organic solvents
}

\author{
TATIANE DE AQUINO ${ }^{1}$, FERNANDA F. ZENKNER ${ }^{1}$, JOEL H. ELLWANGER ${ }^{1,2}$, \\ DANIEL PRÁ ${ }^{1,3}$ and ALEXANDRE RIEGER ${ }^{1}$ \\ ${ }^{1}$ Departamento de Biologia e Farmácia, Universidade de Santa Cruz do Sul/UNISC, Av. \\ Independência, 2293, Bairro Universitário, 96815-900 Santa Cruz do Sul, RS, Brasil \\ ${ }^{2}$ Programa de Pós-Graduação em Biologia Celular e Molecular, Universidade Federal do Rio Grande do Sul/ \\ UFRGS, Campus do Vale, Av. Bento Gonçalves, 9500, 91501-970 Porto Alegre, RS, Brasil \\ ${ }^{3}$ Programa de Pós-Graduação em Promoção da Saúde, Universidade de Santa Cruz do Sul/UNISC, \\ Av. Independência, 2293, Bairro Universitário, 96815-900 Santa Cruz do Sul, RS, Brasil
}

Manuscript received on March 12, 2015; accepted for publication on May 11, 2015

\begin{abstract}
The aim of this study was to evaluate potential DNA damage and cytotoxicity in pathology laboratory technicians exposed to organic solvents, mainly xylene. Peripheral blood and buccal cells samples were collected from 18 technicians occupationally exposed to organic solvents and 11 non-exposed individuals. The technicians were sampled at two moments: Monday and Friday. DNA damage and cytotoxicity were evaluated using the Comet Assay and the Buccal Micronucleus Cytome assay. Fifteen subjects (83.5\%) of the exposed group to solvents complained about some symptom probably related to contact with vapours of organic solvents. DNA damage in the exposed group to solvents was nearly 2-fold higher on Friday than on Monday, and in both moments the individuals of this group showed higher levels of DNA damage in relation to controls. No statistical difference was detected in buccal cell micronucleus frequency between the laboratory technicians and the control group. However, in the analysis performed on Friday, technicians presented higher frequency (about 3-fold) of karyolytic and apoptotic-like cells (karyorrhectic and pyknotic) in relation to control group. Considering the damage frequency and the working time, a positive correlation was found in the exposed group to solvents $(\mathrm{r}=0.468 ; \mathrm{p}=0.05)$. The results suggest that pathology laboratory workers inappropriately exposed to organic solvents have increased levels of DNA damage.
\end{abstract}

Key words: DNA damage, micronucleus, toxicology, occupational health, organic solvents, xylene.

\section{INTRODUCTION}

In recent years, the increased use of petroleumbased products in automobiles and industry has led to important impacts on the environment and human health, mainly caused by the use of volatile organic

Correspondence to: Alexandre Rieger

E-mail: rieger@unisc.br solvents, such as benzene, toluene, ethylbenzene and xylene (Mazzeo et al. 2011). These substances are present in a wide range of products, including industrial paints, aerosols, fuels (Tieyu et al. 2014), starting materials for the manufacture of pesticides, plastics and synthetic fibers (Chen et al. 2008).

Considering the extensive use of volatile organic solvents in industry and the fact that there 
are thousands of workers daily exposed worldwide, it is necessary to assess the chronic exposure to these chemicals. Many studies have evaluated occupational risk of workers from different industries/activities, like paint workers (Cassini et al. 2011), gas station attendants (Trevisan et al. 2014), styrene production workers (Holz et al. 1995), military (Hughes and Hunting 2013), and nurses exposed to antineoplastic drugs (Mahboob et al. 2012).

A relevant group to assess long term occupational risk is pathology laboratory technicians. These individual are chronically exposed to xylene that is one of the most used solvents in pathology laboratories as a clearing agent to prepare tissues for microscopic analysis. Technicians who work with histopathology may be directly in contact with xylene and other potentially hazardous substances. Xylene inhalation causes irritation of nose and throat. Gastric discomfort, nausea and vomiting have also been reported in workers chronically exposed to xylene vapours. Furthermore, skin contact with xylene can cause urticarial, dryness and scaling of the affected area, and skin erythema (Rajan and Malathi 2014).

Although chronic exposure to xylene is associated to harmful effects to human health, the World Health Organization does not consider this chemical substance as genotoxic or carcinogenic (WHO 1996). The results are scarce, but few studies suggested that xylene reduces cell viability and increases DNA damage (Al-Ghamdi et al. 2004, Chen et al. 2008, Singh et al. 2011). Biomonitoring studies must be developed to elucidate cytological alteration in technicians exposed to xylene and other chemical substances.

Therefore, the aim of this study was to evaluate the potential DNA damage and the cytotoxicity in pathology laboratory technicians occupationally exposed to organic solvents, mainly xylene. The technicians were sampled at two moments: before the beginning of the working week (Monday morning) and after the end of the week (Friday evening). This strategy allowed assessing the damage after the weekend recovery (background damage) and the damage originated as a consequence of the work between Monday and Friday. DNA damage and cytotoxicity were evaluated in both moments by the peripheral blood using the Comet Assay and in exfoliated buccal cells using the Buccal Micronucleus Cytome (BMCyt) assay.

\section{MATERIALS AND METHODS}

ETHICAL ASPECTS

The study was approved by the Ethical Committee of the University of Santa Cruz do Sul, Rio Grande do Sul, Brazil (Protocol number: 2448/09). According to the Declaration of Helsinki, all subjects were advised about the procedures and signed an informed consent prior to participation in this study.

SUBJECTS

The exposed group consisted of 18 technicians occupationally exposed to organic solvents (mainly xylene) in a pathology laboratory at Santa Cruz do Sul, Rio Grande do Sul, Brazil. Eleven nonexposed individuals and matched by sex and age to the exposed group were chosen for the control group. They were non-smokers, were not under any medication, and had any occupational risk regarding xylene or other organic solvent exposure. The number of individuals of the exposed group represents the number of individuals exposed to solvents in the laboratory where the study was conducted. The number of control subjects is the number of individuals who performed similar activities to the exposed group (except exposure to solvents) and met the other criteria to be included in the control group. All individuals involved in the study answered a personal questionnaire about lifestyle and working conditions. 


\section{COLLECTION OF BIOLOGiCAL SAMPLES}

Collection of peripheral blood samples was performed with a blood-sampling device with a lancet. Blood from fingertips was collected with a micropipette, and then the sample was immediately transferred to a tube with heparin and protected from the light. Buccal cells were collected with a cytobrush by rotating it in a circular motion into the internal part of the cheeks. Both cheeks were sampled and the buccal cells of each individual were previous mixed. After the collection, cytobrushes were transferred and kept in cell fixation buffer (methanol and acetic acid 3:1) and stored under refrigeration. Before the collection of buccal cells, the individuals conducted a mouth washing with distilled water for 30 seconds in order to clear and remove dead cells and debris.

\section{COMET ASSAY}

The comet assay was performed in the alkaline version according to the protocol described below, adapted from Singh et al. (1988). Blood samples were transported to the laboratory under refrigeration and immediately processed. Slides were prepared by mixing $5 \mu \mathrm{L}$ of peripheral blood with $95 \mu \mathrm{L}$ of low melting point agarose $(0.75 \%)$ kept at $37^{\circ} \mathrm{C}$ in water bath. The mixture was spread onto a microscope slide pre-coated with normal melting point agarose $(1.5 \%)$ and covered with a coverslip. After 10 minutes in the refrigerator to allow agarose solidification, the coverslip was removed and the slides were placed in lysis solution [2.5 M NaCl, $100 \mathrm{mM}$ ethylenediaminetetraacetic acid (EDTA) and $10 \mathrm{mM}$ Tris, $\mathrm{pH}=10.0$, with freshly added $1 \mathrm{~mL}$ Triton X-100 and 10\% dimethyl sulfoxide (DMSO)] for 72 hours. Subsequently, the slides were incubated in freshly made alkaline buffer $(300 \mathrm{mM} \mathrm{NaOH}$ and $1 \mathrm{mM}$ EDTA, $\mathrm{pH}>13)$ for 15 minutes to allow DNA unwinding and exposure of alkali-labile sites. The DNA was electrophoresed for $300 \mathrm{~mA}$ and 20 minutes at 25
$\mathrm{V}(0.9 \mathrm{~V} / \mathrm{cm})$, and the slides were neutralized with $0.4 \mathrm{M}$ Tris ( $\mathrm{pH}$ 7.5). Then, the slides were fixed and stained with silver nitrate (solution A: $5 \%$ sodium carbonate; solution B: $0.1 \%$ ammonium nitrate, silver nitrate $0.1 \%$ tungstosilicic acid $0.25 \%$ and $0.15 \%$ formaldehyde) during 35 minutes under agitation $\left(110 \mathrm{rpm} ; 37^{\circ} \mathrm{C}\right)$ (Nadin et al. 2001).

The electrophoresis procedures and the efficiency for each electrophoresis run were checked using a positive internal control consisting of peripheral human blood treated with hydrogen peroxide $(100 \mu \mathrm{M})$ for 10 minutes at $4^{\circ} \mathrm{C}$. Each electrophoresis run was considered valid just if the positive control yielded the expected result.

The slides were made in triplicate and coded for blind analysis using conventional optical microscopy at 400X magnification. Fifty nucleoids were analyzed per slide, and the damages were visually scored according to tail size into five classes, from no tail (0) to maximal long tail (4). Therefore, the damage frequency (DF, percentage of damage cells) and the damage index (DI) ranging from 0 (all cells with no tail, 100 cells x 0 ) to 400 (all cells with maximally long tails, 100 cells x 4) were calculated for each subject.

\section{BuCCAL MiCRONUCLEUS CYTOME (BMCyt) AsSAY}

The protocol for the Buccal Micronucleus Cytome (BMCyt) assay was adapted from Thomas et al. (2009) as follows. Cells collected from right and left cheeks of an individual and kept in cell fixation buffer were previous mixed in a microtube. Each microtube was vortexed for 30 seconds and the cytobrush were carefully removed. Then, microtubes were centrifuged for 10 minutes at $1500 \mathrm{rpm}\left(12^{\circ} \mathrm{C}\right)$, and the supernatant was replaced by $1 \mathrm{~mL}$ of cell fixation buffer. The centrifugation steps were repeated 3 times and in final step $100 \mu \mathrm{L}$ of cell suspension was dropped onto a microscope slide and immediately spread with the aid of a pipette tip. Fixed cells were hydrolyzed and stained according to Feulgen method (Thomas et al. 2009). 
A total of 4000 cells were scored per individual (two slides each), and classified according to Thomas et al. (2009). Cell types were grouped into categories that distinguish normal cells from abnormal cells classified according to their cytological and nuclear features: indicative of DNA damage (micronucleus; nuclear bud), cytokinesis failure (binucleated cells), or cell death (apoptosis - condensed chromatin, karryorrhectic cells, pyknotic cells; and necrosis - karyolitic cells).

\section{STATISTICAL ANALYSIS}

Statistical analysis was performed using Graph Pad Prism 5.0 (GraphPad Inc, San Diego, California). The results were presented as mean and standard deviation. Categorical variables were expressed as counts or percentages. Comparisons between control and exposed groups were performed using the unpaired two-tailed Student's t-test for continuous variables and Fisher's exact test for discrete variables. Results of BMCyt and Comet Assay were analyzed by Kruskal-Wallis test followed by Dunn post-hoc test. Correlations between the DNA damage markers and the working time (months) was assessed with Pearson's correlation coefficient. The significance level was of $5 \%(p<0.05)$.

\section{RESULTS}

The main features of both groups are shown in Table I. No difference between the age and sex of the technicians $(25.4 \pm 6.1 ; 66.7 \%$ female $)$ and the control group $(24.5 \pm 6.6 ; 63.6 \%$ female $)$ was found. None of the individuals of both groups were smokers, and no differences were observed in relation to drinking and eating habits between the technicians and non-exposed (control) groups (data not shown).

The average working time and the daily exposure time of the technicians, as well as the use of Personal Protective Equipment (PPE) and the main symptoms reported are presented in Table II. The technicians had been working in a pathology laboratory between 1 and 96 months ( 8 years), with daily organic solvents exposure of 4 to 9 hours $(7.5$ $\pm 1.65)$. Xylene was the most used substance during microscope slides preparation, and all technicians reported having direct or indirect contact with it. While some technicians mentioned handling xylene directly, others mentioned remaining in the same room where xylene was being used.

In general, we found that the use of PPE was neglected. All the technicians answered to use the

TABLE I

Characterization of exposed and control groups.

\begin{tabular}{lccc}
\hline & $\begin{array}{c}\text { Exposed group } \\
\mathrm{n}=18\end{array}$ & $\begin{array}{c}\text { Control group } \\
\mathrm{n}=11\end{array}$ & $\mathbf{p}$ \\
\hline $\begin{array}{l}\text { Age (years) } \\
\text { Mean } \pm \text { SD } \\
\text { Range (CI 95\%) }\end{array}$ & $25.4 \pm 6.1$ & $24.5 \pm 6.6$ & $0.71^{\mathrm{a}}$ \\
$\begin{array}{l}\text { Sex, n (\%) } \\
\text { Male }\end{array}$ & $18-39(22.4-28.5)$ & $18-39(20.1-29.0)$ & \\
$\quad$ Female & $6(33.3)$ & & $1.0^{\mathrm{b}}$ \\
Smoking status & $12(66.7)$ & $7(36.4)$ & \\
$\quad$ No. of non-smokers (\%) & & $11(100 \%)$ & \\
Alcohol drinking status & $18(100 \%)$ & $11(100 \%)$ & \\
$\quad$ Drinking habit (only weekends) & $18(100 \%)$ & & \\
\hline${ }^{\mathrm{a}}$ T test ; ${ }^{\mathrm{b}}$ Fisher's exact test. & & &
\end{tabular}


TABLE II

Characteristics and symptoms related to individuals' occupational risk of the exposed group.

\begin{tabular}{|c|c|}
\hline & Exposed group \\
\hline \multicolumn{2}{|l|}{ Average working time (months) } \\
\hline Median & 21 \\
\hline Range (CI 95\%) & $1-96(17.6-52.8)$ \\
\hline \multicolumn{2}{|l|}{ Daily exposure time (hours) } \\
\hline Mean \pm SD & $7.5 \pm 1.65$ \\
\hline Range (CI 95\%) & $4-9(6.6-8.4)$ \\
\hline \multicolumn{2}{|l|}{ Use of Personal Protection Equipment (PPE) (\%) } \\
\hline Laboratory coat & $18(100.0)$ \\
\hline Gloves* & $9(50.0)$ \\
\hline Mask* & 0 \\
\hline Safety glass & 0 \\
\hline Asymptomatics, n (\%) & $3(16.5)$ \\
\hline Symptomatics, n (\%) & $15(83.5)$ \\
\hline \multicolumn{2}{|l|}{ Symptoms, n (\%) } \\
\hline Nose and/or throat irritation & $1(6.7)$ \\
\hline Nose and/or throat irritation + headache & $3(20.0)$ \\
\hline Nose and/or throat irritation + headache + eye irritation & $3(20.0)$ \\
\hline Nose and/or throat irritation + headache + peeling skin & $2(13.3)$ \\
\hline Nose and/or throat irritation + headache + peeling skin + difficulty breathing & $1(6.7)$ \\
\hline Nose and/or throat irritation + headache + nausea + stomach pain + gastritis & $1(6.7)$ \\
\hline Nose and/or throat irritation + peeling skin + stomach pain + gastritis & $1(6.7)$ \\
\hline Headache + stomach pain + difficulty breathing & $1(6.7)$ \\
\hline Stomach pain + nausea & $1(6.7)$ \\
\hline Difficulty breathing & $1(6.7)$ \\
\hline
\end{tabular}

*Only latex gloves and masks not proper against organic solvents were reported to be available.

routine laboratory coat, but none of them use safety glasses, and 50\% related the use only latex gloves. Fifteen subjects $(83.5 \%)$ of the exposed group complained about some symptom probably related to contact with organic vapours. The most common symptoms reported were nose and throat irritation and headache (Table II).

According to the Comet Assay, the technicians had a higher level of DNA damage in relation to controls at both moments analysed (on Monday and on Friday). Among the technicians, the level of DNA damage was nearly 2-fold higher on Friday than on Monday (Table III). Considering the working time and the damage frequency a positive correlation was found in the exposed group (Friday samples, $r=0.468 ; \mathrm{p}=0.05$ ) (Figure 1).

No statistical difference was detected in buccal cell micronucleus frequency between the technicians and the control group. However, in the analysis performed on Friday, technicians presented higher frequency (about 3-fold) of karyolytic and apoptotic-like cells in relation to control group. Also, the frequencies of these types of cells were higher on Friday comparing to Monday among technicians (about 3-fold for karyolytic and 2-fold for apoptotic-like cells) (Table III). 
TABLE III

Comet Assay and Buccal Micronucleus Cytome assay results.

\begin{tabular}{|c|c|c|c|c|c|c|c|c|c|}
\hline \multirow{2}{*}{$\begin{array}{l}\text { Comet Assay (blood cells) } \\
\text { Con }\end{array}$} & \multirow{2}{*}{\multicolumn{3}{|c|}{ Control group }} & \multicolumn{6}{|c|}{ Techicians group } \\
\hline & & & & \multicolumn{3}{|c|}{ Monday } & \multicolumn{3}{|c|}{ Friday } \\
\hline DF (\%) & 8.36 & \pm & 6.47 & 19.11 & \pm & $8.07^{\mathrm{a}^{*}}$ & 33.89 & \pm & $23.91^{\mathrm{a}^{* * *}, \mathrm{~b}^{*}}$ \\
\hline DI (0-400) & 8.36 & \pm & 6.47 & 19.61 & \pm & $7.95^{\mathrm{a}^{*}}$ & 35.56 & \pm & $24.03^{\mathrm{a}^{* * *}, \mathrm{~b}^{*}}$ \\
\hline \multicolumn{10}{|l|}{ BMCyt (\%o) } \\
\hline Micronuclei & 0.07 & \pm & 0.12 & 0.07 & \pm & 0.19 & 0.14 & \pm & 0.16 \\
\hline Binucleated cells & 1.52 & \pm & 0.70 & 1.83 & \pm & 0.91 & 1.38 & \pm & 0.92 \\
\hline Karyolytic cells & 22.84 & \pm & 6.10 & 28.57 & \pm & 20.09 & 93.18 & \pm & $43.04^{\mathrm{a}^{* * *}, \mathrm{~b}^{* * * *}}$ \\
\hline Apoptotic-like cells (sum) & 6.46 & \pm & 1.94 & 9.86 & \pm & 3.97 & 17.56 & \pm & $6.77^{7^{* * *}, b^{* *}}$ \\
\hline Condensed chromatin & 0.43 & \pm & 0.34 & 0.60 & \pm & 0.39 & 1.33 & \pm & 1.71 \\
\hline Karyorrhectic cells & 0.86 & \pm & 0.39 & 1.43 & \pm & 1.06 & 3.31 & \pm & $2.44^{\mathrm{a}^{* * *}, \mathrm{~b}^{* *}}$ \\
\hline Pyknotic cells & 5.16 & \pm & 1.61 & 7.83 & \pm & 3.20 & 12.92 & \pm & $4.40^{\mathrm{a}^{* * *}, \mathrm{~b}^{* *}}$ \\
\hline
\end{tabular}

DF: Damage Frequency (\% cells); DI: Damage Index (arbitrary unit, 0 - 400).

BMCyt: Buccal Micronucleus Cytome assay.

Significant values $(\mathrm{p}<0.05)$; Kruskal-Wallis test with Dunn's post-test.

${ }^{\mathrm{a}}$ : In relation to control group; ${ }^{\mathrm{b}}$ : Monday x Friday (technicians group) $-{ }^{*} \mathrm{p}<0.05 ;{ }^{* *} \mathrm{p}<0.01 ; * * * \mathrm{p}<0.001$

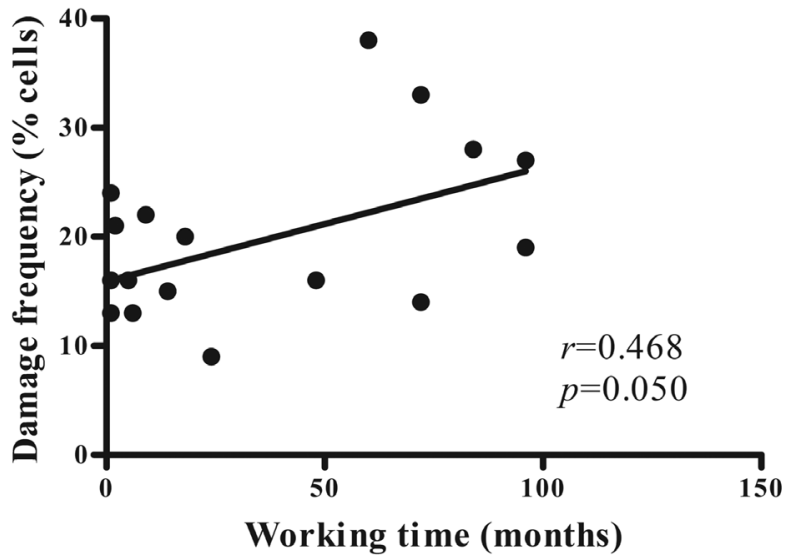

Figure 1 - Correlation between working time and damage frequency as evaluated by the Comet Assay; $r$ and $p$ : correlation coefficient and level of significance, respectively, according to Pearson's correlation.

\section{DISCUSSION}

Xylene is the most used organic solvent in the field of histopathology, applied as a clearing agent to give translucency to the tissues (Rajan and Malathi 2014). Laboratory technicians who prepare slides for histopathological analysis can be directly exposed to this substance. However, the effects of xylene exposure to human health are still controversial, and increasing attention has been given to xylene in occupational exposure (Dick 2006). In this sense, the present work assessed possible adverse effects in individuals occupational exposed to xylene and other organic solvents, including the main symptoms mentioned by them, as well as the use of Personal and Collective Protective Equipment (PPE and CPE), and the DNA damage and cytotoxic effects in these individuals.

Eighteen laboratory technicians were evaluated in this study, and $83.5 \%(\mathrm{n}=15)$ reported some kind of symptom probably related to organic solvent exposure. The main symptoms described were headache, nose and/or throat irritation, peeling skin and symptoms related to the digestive system (nausea, stomach pain or gastritis).

The incorrect use of protective equipment along with daily exposure to organic solvents such as xylene worsens the scene of occupational exposure, what can be translated into symptoms reported by workers. Although all of them used the routine laboratory coat daily, it was not available 
in the laboratory the correct types of gloves and masks. Latex gloves are not appropriate to handling xylene (Tran et al. 2012). The National Institute for Occupational Safety and Health of the United States recommended the use of polyvinyl chloride (PVC), Teflon ${ }^{\mathrm{TM}}$ or Viton ${ }^{\mathrm{TM}}$ gloves to handle xylene (NIOSH 1993). Only latex gloves were reported to be available in the laboratory. Moreover, the disposable surgical masks used by the technicians were also not proper to protect against organic vapors (NIOSH 1978), but air-purifying respirators with an organic vapour cartridge (adequate PPE) were not available in the laboratory. Further, xylene should be manipulated in a fume hood (NIOSH 1993).

Considering the hazardous of xylene to human health, it is extremely important the correct use of PPE and CPE since chronic exposure to this compound has been associated to damages in the nervous system, liver and kidneys (Mazzeo et al. 2011). The lack of appropriated protective equipment use may be the cause of symptoms reported by the technicians. According to Rajan and Malathi (2014), dermal absorption is one of the main routes of xylene exposure, especially among laboratory workers. In a study with rats, after 1 to 2 hours of dermal contact with xylene was reported skin inflammation and epidermal degeneration (Gunasekar et al. 2003). Handling xylene without wear proper gloves or not wearing any gloves may cause the peeling skin mentioned by technicians. Also, inhalation is an important route of exposure to xylene. Xylene should be handled into a fume hood or using respirators with cartridge to organic vapours (NIOSH 1978). However, only $11 \%$ of the technicians answered to manipulate xylene into the fume hood, and no suitable respirators were available in the laboratory. Headache, nose and throat irritation and gastrointestinal symptoms can be related to chronic exposure to xylene vapours (Rajan and Malathi 2014).

Several studies have demonstrated the genotoxic potential of organic solvents in humans and other animals (Singh et al. 2011, Mazzeo et al. 2013, Wang et al. 2013). In this study, we use the Comet Assay to assess the genotoxicity in laboratory technicians' blood samples before and after weekly exposure. The results showed that occupational exposure to xylene can damage the DNA, and the damage increases throughout the week. However, it was observed a relevant reduction in DNA damage during the weekend.

Besides the main route of exposure to xylene be inhalation, xylene metabolism occurs in the liver, explaining the damage caused to blood cells and not just to the epithelial cells, as detected by Comet Assay (EPA 2003). The Comet Assay detects basically DNA damage newly generated, which is repairable depending on the stage of the cell cycle. DNA repair processes can explain the reduction of damage on weekend, when the workers were distant from the workplace and DNA damage returns to baseline (Lorenzo et al. 2013). During the week, as occupational exposure to xylene intensifies, the damage increases.

There is evidence that the primary DNA damage if not properly repaired could be converted into permanent DNA damage that could be measured by an increased frequency of micronucleus or other nuclear abnormalities. The increase of micronucleus was not observed, possibly because of cell death activity, at least in the oral mucosa. Alterations caused in basal cells' nuclei by genotoxic events can be observed three weeks later in exfoliated buccal cells (León-Mejía et al. 2014). Oral epithelium regenerates constantly according to basal cells division rate, their genomic stability, and their propensity for cell death (Thomas et al. 2009). A cell is addressed to programmed cell death when presents irreparable damage, and it is known that DNA damage may cause severe consequences if not repaired, leading to carcinogenesis (Singh et al. 2011). Considering that a high number of cancers have an epithelial origin, the BMCyt assay is considered suitable to assess occupational 
exposure to potentially genotoxic substances, as volatile organic compounds (León-Mejía et al. 2014).

We evaluated the laboratory technicians and the results of BMCyt assay showed higher frequency of apoptotic (karyorrhectic and pyknotic cells) and necrotic-like cells (karyolitic cells) in comparison to control group. Al-Ghamdi et al. (2003) evaluated kidney citotoxicity caused by xylene exposure and their finds indicated that the major form of cell death caused by acute exposure to lethal dose of xylene was necrosis. On the other hand, apoptosis may occur when a chronic exposure to lower doses of solvent is present (Al-Ghamdi et al. 2003).

With these results, we suggest that basal cells are dying earlier as their presented irreparable damage, and have been addressed to apoptotic pathways. The damage is not permanent yet, and there is no increase in micronucleus frequency. However, a high rate of apoptotic cells may increase the chance of micronucleus generation and hence risk of cancer.

Positive correlation between DNA damage frequency and the working time was also found. Cells with extended DNA damage (i.e. with genomic instability) are forwarded to apoptotic pathways, indicated here by increased occurrence of karyorrhectic and pyknotic cells. However, this correlation may highlight that with the exposure time (years in service) increasing, the damage tends to increase enabling a future failure in the cell cycle checkpoints. If cell cycle checkpoints fail, cells that should be directed to apoptosis can continue the cycle, fixing at some extent the DNA alterations.

Furthermore, we can speculate that the organic solvent exposure and the consequent increased rate of cellular events indicative of cell death observed in technicians group compared to control group can stimulate the proliferation of the basal cells' layer. This process could result in premature aging of oral mucosa and enhance the carcinogenesis risk (age-related neoplastic risk). However, there are no conclusive studies about carcinogenesis caused by xylene exposure (IARC 1999). Our suggestion for future studies is to accompany the subjects for a longer period, also focusing other tissues than the oral mucosa, which also could accumulate cellular lesions. Additionally, we intend to enrol a greater number of subjects in future studies. However, it is important to note that the number of subjects used in the present study is in line with guidelines for Comet Assay [at least 3-4 samples of each sex per group, according to Tice et al. (2000) and Hartmann et al. (2003)] and is similar to studies with the BMCyt assay (Azhar et al. 2013, Bolognesi et al. 2015).

\section{ACKNOWLEDGMENTS}

The authors thank all volunteers who participated in this study. This work was supported by Fundação de Amparo à Pesquisa do Estado do Rio Grande do Sul (FAPERGS).

\section{RESUMO}

O objetivo deste estudo foi avaliar potenciais danos no DNA e citotoxicidade em técnicos de laboratório de patologia expostos a solventes orgânicos, principalmente ao xileno. Amostras de sangue periférico e células bucais foram coletadas de 18 técnicos ocupacionalmente expostos a solventes orgânicos e de 11 indivíduos não expostos aos solventes. Os técnicos foram avaliados em dois momentos: segunda-feira e sexta-feira. Danos no DNA e citotoxicidade foram avaliados usando o Ensaio Cometa e o Teste de Micronúcleos e Anomalias Nucleares. Quinze indivíduos (83,5\%) do grupo exposto aos solventes queixaram-se de algum sintoma com provável relação com o contato com vapores de solventes orgânicos. Os danos no DNA no grupo exposto aos solventes foram aproximadamente 2 vezes maiores na sexta-feira do que na segunda-feira, e em ambos momentos os indivíduos desse grupo apresentaram maiores níveis de danos no DNA em relação aos controles. Não foi encontrada diferença significativa na frequência de micronúcleos nas células bucais entre os técnicos de laboratório e os indivíduos do grupo controle. 
Entretanto, na análise realizada na sexta-feira, os técnicos apresentaram maior frequência (aproximadamente 3 vezes) de células cariolíticas e células indicativas de apoptose (cariorréticas e picnóticas) em relação ao grupo controle. Considerando a frequência de dano e o tempo de trabalho, uma correlação positiva foi encontrada entre o grupo de indivíduos expostos aos solventes $(r=0,468 ; p=0,05)$. Os resultados sugerem que técnicos de laboratório de patologia expostos de forma inadequada a solventes orgânicos possuem aumento dos níveis de danos no DNA.

Palavras-chave: danos no DNA, micronúcleos, toxicologia, saúde ocupacional, solventes orgânicos, xileno.

\section{REFERENCES}

AL-GHAMDI SS, RAFTERY MJ AND YAQOOB MM. 2003. Acute solvent exposure induced activation of cytochrome P4502E1 causes proximal tubular cell necrosis by oxidative stress. Toxicol In Vitro 17: 335-341.

AL-GHAMDI SS, RAFTERY MJ AND YAQOOB MM. 2004. Toluene and p-Xylene induced LLC-PK1 apoptosis. Drug Chem Toxicol 27: 425-432.

AZHAR DA, SYED S, LUQMAN M AND ALI AA. 2013. Evaluation of methyl methacrylate monomer cytotoxicity in dental lab technicians using buccal micronucleus cytome assay. Dent Mater J 32: 519-521.

BOLOGNESI C, ROGGIERI P, ROPOLO M, THOMAS P, HOR M, FENECH M, NERSESYAN A AND KNASMUELLER S. 2015. Buccal micronucleus cytome assay: results of an intraand inter-laboratory scoring comparison. Mutagenesis 30: 545-555.

CAssini C, CAlloni C, Bortolini G, Garcia SC, DORNELLES MA, HENRIQUES JAP, ERDTMANN B AND SALVADOR M. 2011. Occupational risk assessment of oxidative stress and genotoxicity in workers exposed to paints during a working week. Int J Occup Med Environ Health 24: 308-319.

Chen CS, HSEu YC, Liang SH, KuO JY AND CHEN SC. 2008. Assessment of genotoxicity of methyl-tert-butyl ether, benzene, toluene, ethylbenzene, and xylene to human lymphocytes using comet assay. J Hazard Mater 153: $351-356$.

DICK FD. 2006. Solvent neurotoxicity. Occup Environ Med 63: $221-226$

EPA - EnVironmental Protection Agency. 2003. Toxicological review of xylenes. Washington, D.C.: EPA.

GuNASEKAR PG, Rogers JV, KABBUR MB, GARRETT CM, BRINKLEY WW AND MCDOUGAL JN. 2003. Molecular and histological responses in rat skin exposed to $m$-Xylene. J Biochem Mol Toxicol 17: 92-94.

HARTMANN A ET AL. 2003. Recommendations for conducting the in vivo alkaline Comet assay. $4^{\text {th }}$ International Comet Assay Workshop. Mutagenesis 18: 45-51.

Holz O ET AL. 1995. Determination of low level exposure to volatile hydrocarbons and genotoxic effects in workers at a styrene plant. Occup Environ Med 52: 420-428.

HuGHES H AND HuNTING KL. 2013. Evaluation of the effects of exposure to organic solvents and hazardous noise among US Air Force Reserve personnel. Noise Health 15: 379-387.

IARC - INTERNATIONAL AGENCY FOR RESEARCH ON CANCER. 1999. IARC Monographs on the evaluation of carcinogenic risk to humans - Re-evaluation of some organic chemicals, hydrazine and hydrogen peroxide. Vol. 71, Lyon: WHO - IARC.

LEÓN-MEJía G, Quintana M, Debastiani R, Dias J, ESPITIA-PÉREZ L, HARTMANN A, HENRIQUES JAP AND DA SILVA J. 2014. Genetic damage in coal miners evaluated by buccal micronucleus cytome assay. Ecotoxicol Environ Saf 107: 133-139.

Lorenzo Y, Costa S, COLlins AR AND AZQUETA A. 2013. The comet assay, DNA damage, DNA repair and citotoxicity: hedgehogs are not always dead. Mutagenesis 28: 427-432.

MAHBOOB M, RAHMAN MF, REKHADEVI PV, SAILAJA N, BALASUBRAMANYAM A, PRABHAKAR PV, SINGH SP, REDDY UA, RAO GS AND GROVER P. 2012. Monitoring of oxidative stress in nurses occupationally exposed to antineoplastic drugs. Toxicol Int 19: 20-24.

MAZZEO DEC, FERNANDES TCC AND MARIN-MORALES MA. 2011. Cellular damages in the Allium cepa test system, caused by BTEX mixture prior and after biodegradation process. Chemosphere 85: 13-18.

Mazzeo DEC, Matsumoto ST, LeVy CE, De ANGelis DF AND MARIN-MORALES MA. 2013. Application of micronucleus test and comet assay to evaluate BTEX biodegradation. Chemosphere 90: 1030-1036.

NADIN SB, VARGAS-ROIG LM AND CIOCCA DR. 2001. A silver staining method for single-cell gel assay. J Histochem Cytochem 49: 1183-1186.

NIOSH - NATIONAL INSTITUTE FOR OCCUPATIONAL SAFETY AND HEALTH. 1978. Occupational health guideline for xylene. US Department of Health and Human Services, Public Health Service, CDC.

NIOSH - NATIONAL INSTITUTE FOR OCCUPATIONAL SAFETY AND HEALTH. 1993. Health hazard evaluation report $n^{\circ}$ 92-0285. US Department of Health and Human Services, Public Health Service, CDC.

RAJAN ST AND MALATHI N. 2014. Health hazards of xylene: a literature review. J Clin Diagn Res 8: 271-274. 
SINGH MP, MiSHRA M, SHARMA A, SHUKLA AK, MUDIAM MKR, PATEL DK, RAM KR AND CHOWDHURI DK. 2011. Genotoxicity and apoptosis in Drosophila melanogaster exposed to benzene, toluene and xylene: Attenuation by quercetin and curcumin. Toxicol Appl Pharmacol 253: 14-30.

SINGH NP, MCCOY MT, TICE RR AND SCHNEIDER EL. 1988. A simple technique for quantitation of low levels of DNA damage in individual cells. Exp Cell Res 175: 184-191.

TICE RR ET AL. 2000. Single cell gel/comet assay: guidelines for in vitro and in vivo genetic toxicology testing. Environ Mol Mutagen 35: 206-221.

TIEYU W, BO P, BING T, ZHAOYUN Z, LIYU D AND YONGLONG L. 2014. Benzene homologues in environmental matrixes from a pesticide chemical region in China: Occurrence, health risk and management. Ecotoxicol Environ Saf 104: 357-364.

ThOMAS P, HOLLAND N, BOLOGNESI C, KIRSCH-VOLDERS M, BONASSI S, ZEIGER E, KNASMUELLER S AND FENECH
M. 2009. Buccal micronucleus cytome assay. Nat Protoc 4: 825-837.

Tran JQ, CEBAllos DM, Dills RL, Yost MG AND MORGAN MS. 2012. Transport of a solvent mixture across two glove materials when applied in a paint matrix. Arch Environ Contam Toxicol 63: 169-176.

TREVisan P, DA Silva JN, DA SILVA AP, Rosa RFM, PASKULIN GA, THIESEN FV, DE OLIVEIRA CAV AND ZEN PRG. 2014. Evaluation of genotoxic effects of benzene and its derivatives in workers of gas stations. Environ Monit Assess 186: 2195-2204.

WANG F, LI C, LIU W AND JIN Y. 2013. Oxidative damage and genotoxic effect in mice caused by sub-chronic exposure to low-dose volatile organic compounds. Inhal Toxicol 25: 235-242.

WHO - WORLd HEALTH ORGANIZATION. 1996. Xylenes in drinking water. Guidelines for drinking-water quality, $2^{\text {nd }}$ ed., vol. 2. Geneva: WHO. 